\title{
THE INFLUENCE OF ESTRADIOLE AND TIBOLONE ADMINISTRATION ON LEPTIN LEVELS IN WOMEN WITH SURGICALLY INDUCED MENOPAUSE
}

\author{
Martin Petzel $^{\mathrm{a} *}$, David Stejskal ${ }^{\mathrm{b}}$, Libor Jedelsky ${ }^{\mathrm{b}}$, Lenka Kadalova ${ }^{\mathrm{b}}$, Kristian Safarcik ${ }^{\mathrm{c}}$
}

${ }^{a}$ Department of Obsteric and Gynecology, University Hospital Ostrava Poruba, Czech Republic,

${ }^{b}$ Department of Laboratory Medicine and Internal Department, Sternberk Hospital, Czech Republic

c Department of Nuclear Medicine, University Hospital, Ostrava Poruba, Czech Republic

e-mail:M.Petzel@seznam.cz

Received: April 22, 2008; Accepted: May 23, 2008

Key words: Menopause/Leptin/Estradiole/Tibolone/HRT

Background: Several studies suggest that changes in estrogens and androgens during menopause play a role in the regulation of leptin production. Some authors present hypothesis that sex hormone replacement therapy can modulate leptin levels but up to date evidence shows that the influence of endogenous estrogens, androgens levels and sex hormone therapy on leptin concentration remains uncertain.

Aim: To evaluate the influence of surgically induced menopause on serum leptin levels and the influence of different types of hormonal therapy on serum leptin concentrations.

Methods: 58 women with surgically induced menopause were divided into three groups. Women who did not receive any hormonal substitution (group 1), women who received Estradiol $1 \mathrm{mg}$ per day (group 2) and women who received Tibolone 2,5 mg per day (group3). The levels of leptin, estradiol, testosterone, testosterone, dehydroepiandrosterone sulfate, FSH, LH and progesterone were measured in all subjects on the 5th day and after 3 months following the surgical procedure.

Results: Mean serum leptin concentrations did not differ statistically in any of the studied groups in the begining and in the end of the study. There was no correlations between serum leptin and estradiol, LH, FSH, progesterone, testosterone, free testosterone and DHEAS concentrations in any of groups before and after treatment.

Conclusion: Changes in sex hormone concentrations caused by ovariectomy do not influence serum leptin concentrations. Also the short term administration of low dose estrogen therapy or tibolone in postmenopausal subjects does not change serum leptin levels.

\section{INTRODUCTION}

The loss of estrogens caused by menopause in women is associated with metabolical changes which cause changes in the amount and distribution of body fat ${ }^{1}$. Mechanisms of the influence of sex hormones on body fat and its distribution remain uncertain. Among the different possible mechanisms a link between sex hormones and leptin metabolism has been suggested ${ }^{2-10}$. Leptin, the adipocyte-specific product of the ob gene, plays an important role in food intake, fat metabolism, energy homeostasis and obesity. Leptin together with other hormones regulate eating behavior and body mass ${ }^{11}$. Leptin exerts its effects through interaction with six types of receptors. Leptin receptors are divided into secretory (ObRe), long (ObRb) and short forms (ObRa, ObRc, ObRd, ObRf). (ObRe) acts as a binding protein for leptin in the plasma in humans and mice and is important for leptin transfer into the brain. $\mathrm{ObRb}$ is the only receptor isoform that contains active intracellular signaling domains. This receptor is found in a number of hypothalamic nuclei where it exerts its effects. Action of Leptin on hypothalamic centers, decreases appetite and also probably controls the activity of the thyroid, adrenal, growth, gonadal and lactational axes. Serum leptin levels are strongly related to body fat mass and are regulated by insulin, cortisol, the adrenergic system and other hormones ${ }^{12}$. Several studies suggest that sex hormones, such as estrogens and androgens, may play an role in the regulation of leptin production ${ }^{4,13,14}$. The influence of endogenous estrogens, androgens levels and sex hormone replacement therapy on leptin secretion and serum leptin concentration remains uncertain. Some authors have shown that estrogens have effect on serum leptin levels, while others reported a lack of such influence $^{5,12,15,16}$. The aim of the present study was to evaluate the influence of decrease of endogenous sex hormones during 3 months after surgically induced menopause on serum leptin levels and the influence of different types of hormonal therapy (low dose estrogen therapy or tibolone administration) on serum leptin concentrations in postmenopausal subject.

\section{METHODS}

\section{Patients}

The study group consisted of 57 women with surgically induced menopause. All women underwent surgical procedure - vaginal or abdominal hysterectomy with bilateral adnexectomy. The mean age of women which were taking 
part in the study was 47.3 years. The mean BMI of all subjects in the beginning of the study was 27.2.

Subjects were divided into three groups: 22 women did not receive any hormonal substitution (group 1), 25 women received hormonal therapy - Estradiol $1 \mathrm{mg}$ dosis per day (group 2). 10 women received Tibolone $2.5 \mathrm{mg}$ per day (group 3). Administration of medication in group 2 and 3 was started on the 5 th day after surgery. All subjects gave their informed consent according to the Helsinki Declaration.

\section{Blood collection and laboratory examination}

The examination of biological material was made from venous serum samples. All parameters except leptin were determined within 120 minutes after collection. Venous blood was drawn from all individuals on the 5th day after surgery and after 3 months after surgery. For all subjects, medical data were obtained and a complete physical examination was performed. Weight and height values were recorded. The degree of obesity was described by the body mass index (BMI). Collected serum was assayed for leptin with a microplate enzyme immunoanalytical method (ELISA, BioVendor), estradiol (LEIA, SMSD), testosterone (LEIA, SMSD), free testosterone (ELISA, BioVendor), dehydroepiandrosterone sulfate (DHEAS, LEIA, SMSD), FSH (LEIA, SMSD), LH (LEIA, SMSD), progesterone (LEIA, SMSD).

\section{Inclusion and exclusion criteria}

Inclusion criteria - women who underwent surgical procedure - hysterectomy and bilateral adnexectomy for benign indication with regular menstruation cycle before surgery.

Exclusion criteria included elevation of CRP and diabetes treated with insulin on insulinotherapy.

\section{Statistical data processing}

Data were processed by means of the Medcalc software. Associated constants are expressed as mean \pm standard deviation and median, unless indicated otherwise. The levels of Reg-I $\alpha$ in the subgroups were compared by variance analysis (ANOVA, Kruskal-Wallis according to distribution type) and by means of ROC analysis. The leptin concentration as well as other quantities were mutually correlated using the Spearmann correlation coefficient. Category data were compared by the $\chi^{2}$ test. Value of $p<$ 0.05 was considered as statistically significant. Normality was evaluated by the $\chi^{2}$ test.

\section{RESULTS}

Mean serum leptin concentrations did not differ statistically in any of the studied groups in the begining and also in the end of the study (Tables 1, 2, and 3), (Graph1). Statistical analysis showed no correlations between serum leptin and estradiol, LH, FSH, progesterone, testosterone, free testosterone and DHEAS concentrations in any of groups before and after treatment.

\section{DISCUSSION}

Leptin is involved in body-weight regulation and energy balance ${ }^{11,17,18}$. As an endocrine mediator, leptin also fulfils other tasks, all intreactions of this hormone are still not completely understood. Some studies have reported that estrogens can contribute in regulation of leptin production and its serum concentration ${ }^{19}$. Results of many authors support this theory, they have reported genderrelated differences in leptin concentration between men and women ${ }^{20,21}$. These differences may be partly explained by variability in the amounts of subcutaneous adipose tissue $^{22}$.

Women in general have more body fat than men, and different fat distribution. The serum leptin concentration is closely positively related to fat mass. Women have more subcutaneous fat than visceral fat, while the opposite condition is present in men. It has been shown that subcutaneous fat expresses more leptin mRNA than abdominal fat, this may partially explain the gender differences in leptin levels between the sexes ${ }^{23}$. Despite this evidence it has also been suggested that serum leptin concentrations may be related to differences in estrogen concentrations. Physiological sex hormones fluctuations are present during menstruation cycle. Results published on serum leptin levels caused by hormonal changes during the physiological menstrual cycle vary considerably. Some studies showed significant increase in the late follicular phase, and some did so on the day of the onset of the luteinising hormone $(\mathrm{LH})^{24,25}$. Other investigations described significant increase in serum leptin levels in the late luteal phase $^{26-31}$. Other authors reported only small, not statistically significant variations during the menstrual cycle $\mathrm{e}^{32-34}$. Menopausal transition is marked by a fall in the level of estrogen and a rise in levels of serum follicle-stimulating hormone (FSH) and luteinizing hormone( $\mathrm{LH})$.

The influence of menopause on leptin levels is poorly understood. Various studies have shown differences in leptin values in pre- and postmenopausal women. Rosenbaum and associates ${ }^{20}$ suggested that the leptin concentration is lower in postmenopausal than in premenopausal women, also Ayub N, et al. showed a highly significant diference in comparison of the mean serum leptin concentrations between pre -menopausal and postmenopausal non-obese women ${ }^{16}$. Di Carlo and co-workers observed an increased serum leptin level in untreated postmenopausal women compared with premenopausal values ${ }^{25}$.

On the other hand some investigators didn't show any diference in leptin levels in postmenopausal women a decrease of endogenous estradiole levels did not exert any effect on serum leptin levels ${ }^{5,12,16,17}$. They hypothesize that circulating levels of leptin are not related to the estrogen levels. Our results are in accordance with their conclusions. We did not observe any correlations between serum leptin levels and E2, progesterone, LH and FSH in any of the study groups.

The influence of hormone replacement therapy in postmenopausal women on serum leptin concentration is still poorly understood. Some authors such as Di Carlo and co-workers suggested that sex hormone replacement thera- 

induced menopause

Table 1. Mean values of measured parameters on the 5th day after surgery and 3 months after surgery - Group 1.

\begin{tabular}{|c|c|c|c|c|c|c|c|c|}
\hline & $\begin{array}{l}\text { Leptin } \\
\mathrm{Ng} / \mathrm{ml}\end{array}$ & $\begin{array}{c}\text { Estradiol } \\
\text { umol/1 }\end{array}$ & $\begin{array}{l}\text { Progesterone } \\
\text { nmol/1 }\end{array}$ & $\begin{array}{l}\mathrm{LH} \\
\mathrm{u} / 1\end{array}$ & $\begin{array}{c}\text { FSH } \\
\mathrm{u} / 1\end{array}$ & $\begin{array}{c}\text { Testosterone } \\
\mathrm{nmol} / 1\end{array}$ & $\begin{array}{c}\text { Free } \\
\text { Testosterone } \\
\%\end{array}$ & $\begin{array}{l}\text { SHBG } \\
\mathrm{nmol} / 1\end{array}$ \\
\hline $\begin{array}{l}\text { 胥 } \\
\text { 壳 } \\
\text { n }\end{array}$ & $\begin{array}{c}19.787 \\
\text { SD } 16.9362\end{array}$ & $\begin{array}{c}0.0231 \\
\text { SD } 0.008997\end{array}$ & $\begin{array}{c}0.72 \\
\text { SD } 0.5385\end{array}$ & $\begin{array}{c}22.912 \\
\text { SD } 17.8378\end{array}$ & $\begin{array}{c}54.484 \\
\text { SD } 34.6942\end{array}$ & $\begin{array}{c}0.97 \\
\text { SD } 0.182\end{array}$ & $\begin{array}{c}1.187 \\
\text { SD } 0.6919\end{array}$ & $\begin{array}{c}75.36 \\
\text { SD } 36.0623\end{array}$ \\
\hline 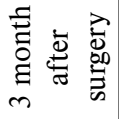 & $\begin{array}{c}20.228 \\
\text { SD } 13.4068\end{array}$ & $\begin{array}{c}0.0483 \\
\text { SD } 0.09226\end{array}$ & $\begin{array}{c}0.457 \\
\text { SD } 0.15701\end{array}$ & $\begin{array}{c}39.025 \\
\text { SD } 15.9099\end{array}$ & $\begin{array}{c}85.641 \\
\text { SD } 43.183\end{array}$ & $\begin{array}{c}1.005 \\
\text { SD } 0.3664\end{array}$ & $\begin{array}{c}1.694 \\
\text { SD } 0.7514\end{array}$ & $\begin{array}{c}65.625 \\
\text { SD } 29.5767\end{array}$ \\
\hline
\end{tabular}

Table 2. Mean values of measured parameters on the 5th day after surgery and 3 months after surgery - Group 2.

\begin{tabular}{|c|c|c|c|c|c|c|c|c|}
\hline & $\begin{array}{l}\text { Leptin } \\
\mathrm{Ng} / \mathrm{ml}\end{array}$ & $\begin{array}{c}\text { Estradiol } \\
\text { umol/1 }\end{array}$ & $\begin{array}{c}\text { Progesterone } \\
\mathrm{nmol} / 1\end{array}$ & $\begin{array}{l}\mathrm{LH} \\
\mathrm{u} / 1\end{array}$ & $\begin{array}{c}\text { FSH } \\
\mathrm{u} / 1\end{array}$ & $\begin{array}{c}\text { Testosterone } \\
\mathrm{nmol} / 1\end{array}$ & $\begin{array}{c}\text { Free } \\
\text { Testosterone } \\
\%\end{array}$ & $\begin{array}{l}\text { SHBG } \\
\mathrm{nmol} / 1\end{array}$ \\
\hline $\begin{array}{l}\text { 吾 } \\
\text { 营 }\end{array}$ & $\begin{array}{c}17.369 \\
\text { SD } 12.0589\end{array}$ & $\begin{array}{c}0.0333 \\
\text { SD } 0.03091\end{array}$ & $\begin{array}{c}1.357 \\
\text { SD } 0.30184\end{array}$ & $\begin{array}{c}20.095 \\
\text { SD } 14.5214\end{array}$ & $\begin{array}{c}35.164 \\
\text { SD } 23.2582\end{array}$ & $\begin{array}{c}0.844 \\
\text { SD } 0.4207\end{array}$ & $\begin{array}{c}1.394 \\
\text { SD } 1.0805\end{array}$ & $\begin{array}{c}79.773 \\
\text { SD } 50.3917\end{array}$ \\
\hline 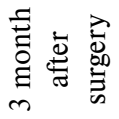 & $\begin{array}{c}24.488 \\
\text { SD } 13.814\end{array}$ & $\begin{array}{c}0.12 \\
\text { SD } 0.07323\end{array}$ & $\begin{array}{c}0.675 \\
\text { SD } 0.4303\end{array}$ & $\begin{array}{c}29.92 \\
\text { SD } 15.9001\end{array}$ & $\begin{array}{c}47.545 \\
\text { SD } 27.2945\end{array}$ & $\begin{array}{c}0.85 \\
\text { SD } 0.5236\end{array}$ & $\begin{array}{c}1.9 \\
\text { SD } 1.2929\end{array}$ & $\begin{array}{c}65.85 \\
\text { SD } 36.2161\end{array}$ \\
\hline
\end{tabular}

Table 3. Mean values of measured parameters on the 5th day after surgery and 3 months after surgery - Group 3.

\begin{tabular}{|c|c|c|c|c|c|c|c|c|}
\hline & $\begin{array}{l}\text { Leptin } \\
\mathrm{Ng} / \mathrm{ml}\end{array}$ & $\begin{array}{c}\text { Estradiol } \\
\text { umol/1 }\end{array}$ & $\begin{array}{l}\text { Progesterone } \\
\text { nmol/1 }\end{array}$ & $\begin{array}{l}\mathrm{LH} \\
\mathrm{u} / 1\end{array}$ & $\begin{array}{c}\text { FSH } \\
\mathrm{u} / 1\end{array}$ & $\begin{array}{l}\text { Testosterone } \\
\text { nmol/1 }\end{array}$ & $\begin{array}{c}\text { Free } \\
\text { Testosterone } \\
\%\end{array}$ & $\begin{array}{l}\text { SHBG } \\
\mathrm{nmol} / 1\end{array}$ \\
\hline 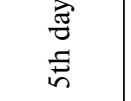 & $\begin{array}{c}19.361 \\
\text { SD } 13.7038\end{array}$ & $\begin{array}{c}0.029 \\
\text { SD } 0.0297\end{array}$ & $\begin{array}{c}0.76 \\
\text { SD } 0.4551\end{array}$ & $\begin{array}{c}28.14 \\
\text { SD } 13.5112\end{array}$ & $\begin{array}{c}49.36 \\
\text { SD } 22.9652\end{array}$ & $\begin{array}{c}0.944 \\
\text { SD } 0.3175\end{array}$ & $\begin{array}{c}1.48 \\
\text { SD } 0.9307\end{array}$ & $\begin{array}{c}74.5 \\
\text { SD } 56.5\end{array}$ \\
\hline 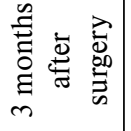 & $\begin{array}{c}18.911 \\
\text { SD } 13.5322\end{array}$ & $\begin{array}{c}0.0363 \\
\text { SD } 0.05617\end{array}$ & $\begin{array}{c}0.625 \\
\text { SD } 0.3012\end{array}$ & $\begin{array}{c}34.05 \\
\text { SD } 8.986\end{array}$ & $\begin{array}{c}49.05 \\
\text { SD } 25.9853\end{array}$ & $\begin{array}{c}0.717 \\
\text { SD } 0.3667\end{array}$ & $\begin{array}{c}2.5 \\
\text { SD } 1.8616\end{array}$ & $\begin{array}{c}35.25 \\
\text { SD } 32.5\end{array}$ \\
\hline
\end{tabular}

py can modulate leptin levels. In their study, an increased serum leptin level in untreated postmenopausal women decreased to premenopausal values after hormonal treatment $^{35}$. In study of Elbers et al. transdermal oestrogen replacement therapy during 2 months in postmenopausal women slightly increased total serum leptin levels ${ }^{36}$. The study of Cagnaci et al. presented different results. Low doses of transdermal estradiol did not exert any influence on fasting leptin levels ${ }^{37}$. Some investigators take the possibility into account that differences in leptin level may rather depend on the dose and type of hormonal therapy used $^{38}$. They suggest that only a supraphysiological estro- gen or gestagen concentration can act on adipocytes and modulate leptin production. But the conclusions of other authors do not support this theory. In study of Castello branco et al. women were randomly allocated to either one of three different doses of norethisterone ( 50 microg/ day, $175 \mathrm{microg} /$ day, or $550 \mathrm{microg} /$ day) continuously combined with a fixed dose of 17beta-estradiol (350 microg/day) for nasal administration, or 17beta-estradiol at $2 \mathrm{mg} /$ day combined with oral norethisterone acetate at $1 \mathrm{mg} /$ day both intranasal and oral therapy had the same effect of increasing the levels of leptin after 24 weeks of administration $^{39}$. Laivuori and co-workers in a 1-year com- 


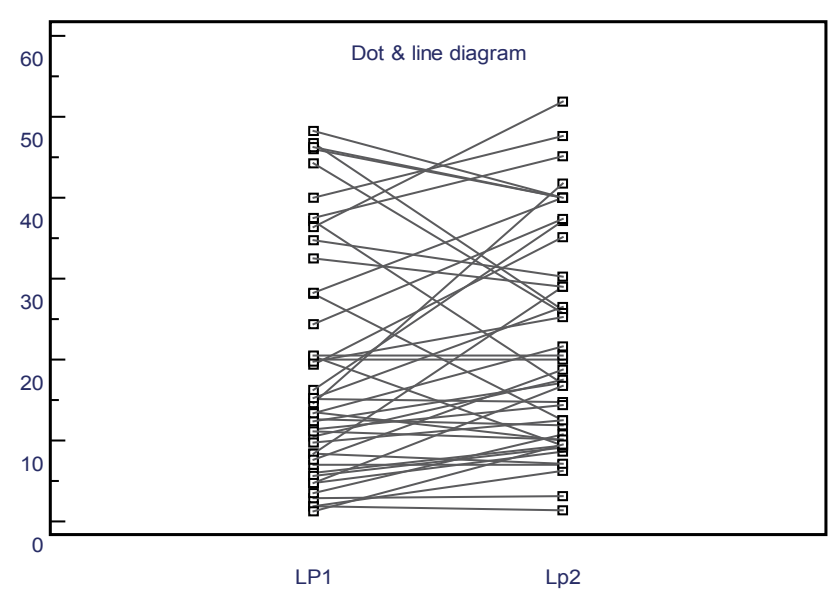

Fig. 1. Leptin concentration after 5 days and 3 months after surgery.

LP1 - leptin values after 5 days, LP2 - leptin values 3 months after surgery

parative study did not find any diference between oral or transdermal therapy in postmenopausal women treated with oral or transdermal $E^{\wedge} \operatorname{sub} 2^{\wedge}+$ NETA. Neither oral nor transdermal $\mathrm{E}^{\wedge} \mathrm{sub} 2^{\wedge}+$ NETA caused any significant change in plasma leptin concentrations or BMI after 2, 6 and 12 months of treatment ${ }^{40}$. In our study, hormonal changes during surgically induced menopause, administration of low dose estrogen therapy or tibolone did not exert any effect on serum leptin levels. These results indicate that sex hormone replacement therapy has no effect on serum leptin concentration.

Several investigators performed studies in postmenopausal women in which tibolone (a selective tissue estrogenic activity regulator) was administered. Tibolone administration relieves climacteric complaints and prevents bone loss without stimulating the endometrium and breast. Tibolone is metabolized in the liver and intestine into $3 \alpha$ - and $3 \beta$-hydroxy metabolites and the 3 -keto- $\Delta^{4}$ metabolite. The 3-hydroxy metabolites activate only the estrogen receptor (ER), whereas the 3-keto- $\Delta^{4}$ metabolite stimulates both progesterone and androgen receptors, but not the ER. Tibolone does not stimulate the endometrium because it is converted locally into its metabolically stable 3-keto- $\Delta^{4}$ metabolite, which shows progestogenic activity. We did not observe any effect of tibolone administration on leptin concentration. Our results are in agreement with results of Tommaselli GA. He compared leptin levels in untreated postmenopausal women and postmenopausal women treated with tibolone. No significant change in serum leptin levels was found in subjects receiving tibolone $^{41}$. Also Lambrinoudaki et al. evaluated the effect of tibolone and also estrogen replacement therapy (ERT) and continuous combined hormone replacement therapy (HRT) on serum leptin levels in healthy postmenopausal Neither ERT/HRT or tibolone exerted any effect on serum leptin after 6 months of treatment ${ }^{42}$. Odabasi et al. studied the effects of tibolone on leptin levels in a 6-month, prospective, randomized, double-blind, placebo- controlled study. Tibolone decreased leptin levels, total fat percentage, and total fat mass ${ }^{43}$. Deogou et al. compared the changes in body composition and in leptin levels in postmenopausal women receiving hormone therapy (HT) or tibolone for 6 months. Women in the tibolone group had a significant decrease in leptin levels accompanied by decreased total fat mass, fat percentage, and increased total lean mass ${ }^{44}$. In our study during 3 months of tibolone administration we did not observe any effect of tibolone on serum leptin levels.

Up to date the influence of endogenous estrogens and androgens levels changes during menopause and the influence of sex hormone replacement therapy on leptin secretion and serum leptin concentration remains uncertain. Based on our result we can conclude that in our study changes in sex hormone concentrations caused by ovariectomy did not influence serum leptin concentrations. We did not observe any changes in leptin levels during 3 months after surgically induced menopause. We did not find any link between sex hormone levels changes in postmenopausal women and leptin concentration. Also the administration of short term low dose estrogen therapy or administration of tibolone in postmenopausal subjects did not change serum leptin levels. Our results are in conclusion with results of authors who also did not find any relation between leptin level and menopausal status. The differences between our results and results of authors who have found different leptin values between pre- and postmenopausal women can be explained by specific composition of our sample (relatively low age of patients who underwent surgical procedure). Also most of the subjects were non-obese women with low BMI, which is resulting in low leptin levels and low incidence of leptin resistance. Our results also reflect metabolic and hormonal changes only in a short period of 3 months after surgically induced menopause.

\section{REFERENCES}

1. Björkelund C, Lissner L, Andersson S, Lapidus L, Bengtsson C. Reproductive history in relation to relative weight and fat distribution. Int J Obes Related Metab Disord 1996; 20:213-219.

2. Al-Harithy RN. Relationship of leptin concentration to gender, body mass index and age in Saudi adults. Saudi Med J 2004; 25:1086-1090.

3. Wu-Peng S, Rosenbaum M, Nicolson M, Chua SC, Leibel RL. Effects of exogenous gonadal steroids on leptin homeostasis in rats. Obes Res 1999; 7:586-592.

4. Lavoie HB, Taylor AE, Sharpless JL, Anderson EJ, Strauss CC, Hall JE. Effects of short-term replacement of serum leptin levels in postmenopausal women. Clin Endocrinol (Oxf) 1999; 51:415-22.

5. Hadji P, Gorke K, Hars O, Bauer T, Emons G, Schulz KD.The influence of hormone replacement therapy (HRT) on serum leptin concentrations in postmenopausal women. Maturitas 2000; 37:105111.

6. Hadji P, Hars O, Bock K, Sturm G, Bauer T, Emons G, et al.. The influence of menopause and body mass index on serum leptin concentrations. Eur J Endocrinol 2000; 143:55-60.

7. Gol M, Ozsener S, Sendag F, Uretmen S, Oztekin K, Tanyalcin $\mathrm{T}$ et al. Does tibolone affect serum leptin levels and body weight in postmenopausal women? ArchGynecol Obstet 2005; 272:127130. 
8. Panidis DK, Rousso DH, Kourtis AI, Stergiopoulos KN, Mavromatidis GA, Katsikis IK. The influence of tibolone upon serum leptin levels in post-menopausal women. Eur J Obstet Gynecol Reprod Biol 2001; 96:85-87.

9. Sumner AE, Falkner B, Kushner H, Considine RV. Relationship of leptin concentration to gender, menopause, age, diabetes, and fat mass in African Americans. Obes Res 1998; 6:128-133.

10. Milewicz A, Bidzińska B, Mikulski E, Demissie M, Tworowska U. Influence of obesity and menopausal status on serum leptin, cholecystokinin, galanin and neuropeptide Y levels. Gynecol Endocrinol 2000;13:1-8.

11. Bluher S, Mantzoros CS. The role of leptin in regulating neuroendocrine function in humans. J Nutr 2004; 134:2469-2474.

12. Lambrinoudaki I, Christodoulakos G, Panoulis C, Botsis D, Rizos D, Augoulea A, et al. Determinants of serum leptin levels in healthy postmenopausal women. J Endocrinol Invest 2003; 26:12251230 .

13. Di Carlo C, Tommaselli GA, Gargano V, Sammartino A, Bifulco G, Tauchmanova L et al.. Effects of estrogen-progestin therapy on serum levels of RANKL, osteoprotegerin, osteocalcin, leptin, and ghrelin in postmenopausal women. Menopause 2007; 14:7-9.

14. Di Carlo C, Tommaselli GA, Di Spiezio Sardo A, Sammartino A Attianese W,et al. Longitudinal evaluation of serum leptin and bone mineral density in early postmenopausal women. Menopause 2007; 14:450-454.

15. Douchi T, Iwamoto I, Yoshimitsu N, Kosha S, Nagata Y. Leptin production in pre- and postmenopausal women. Maturitas 2002; 42:219-223.

16. Ayub N, Khan SR, Syed F. Links Leptin levels in pre and post menopausal Pakistani women. J Pak Med Assoc. 2006; 56:3-5.

17. Friedman JM, Halaas JL. Leptin and the regulation of body weight in mammals. Nature 1998; 395:763-770.

18. Wauters M, Considine RV, Van Gaal LF. Human leptin: from an adipocyte hormone to an endocrine mediator. Eur J Endocrinol 2000; 143:293-311.

19. Shimizu H, Shimomura Y, Nakanishi Y, Futawatari T, Ohtani K, Sato N, Mori M. Estrogen increases in vivo leptin production in rats and human subjects. J Endocrinol 1997; 154:285-292.

20. Rosenbaum M, Nicolson M, Hirsch J, Heymsfield SB, Gallagher D, Chu F, Leibel RL. Effects of gender, body composition, and menopause on plasma concentrations of leptin. J Clin Endocrinol Metab 1996; 81:3424-3427.

21. Havel PJ, Kasim-Karakas S, Dubuc GR, Mueller W, Phinney SD. Gender differences in plasma leptin concentrations. Nat Med 1996; 29:949-950.

22. Augoulea A, Mastorakos G, Lambrinoudaki I, Christodoulakos G, Creatsas G Role of postmenopausal Hormone Replacement Therapy on Body Fat Gain and Leptin Levels Gynecol Endocrinol. 2005; 20:227-235.

23. Lönnqvist F, Arner P, Nordfors L, Schalling M. Overexpression of the obese (ob) gene in adipose tissue of human obese subjects. Nat Med 1995; 1:950-953.

24. Mannucci E, Ognibene A, Becorpi A, Cremasco F, Pellegrini S, Ottanelli S et al. Relationship between leptin and oestrogens in healthy women. European Journal of Endocrinology 1998; 139:198201.

25. Riad-Gabriel MG, Jinagouda SD, Sharma A, Boyadjian R, SaadMF Changes in plasma leptin during the menstrual cycle. European Journal of Endocrinology 1998; 139:528-531.

26. Geisthövel F, Jochmann N, Widjaja A, Horn R, Brabant G. Serum pattern of circulating free leptin, bound leptin, and soluble leptin receptor in the physiological menstrual cycle. Fertility and Sterility 2004; 81:398-402.

27. Ludwig M, Klein HH, Diedrich K, Ortmann O. Serum leptin concentrations thoughout the menstrual cycle. Archives of Gynecology and Obstetrics 2000; 263:99-101.
28. Hardie L, Trayhurn P, Abramovich D, Fowler P. Circulating leptin in women: a longitudinal study in the menstrual cycle and during pregnancy. Clinical Endocrinology 1997; 47:101-106.

29. Quinton ND, Laird SM, Okon MA, Li TC, Smith RF, Ross RJ et al. Serum leptin levels during the menstrual cycle of healthy fertile women. British Journal of Biomedical Science 1999; 56:16-19.

30. Lukaszuk K, Liss J, Kusiak E, Wojcikowski C. Serum leptin concentration increase during luteal phase in healthy premenopausalwomen. Hormone and Metabolic Research 1998; 30:172-173.

31. Stock SM, Sande EM \& Bremme KA. Leptin levels vary significantly during the menstrual cycle, pregnancy, and in vitro fertilization treatment: possible relation to estradiol. Fertility and Sterility 1999; 72:657-662.

32. Teirmaa T, Luukkaa V, Rouru J, Koulu M, Huupponen R. Correlation between circulating leptin and luteinizing hormone during the menstrual cycle in normal-weight women. European Journal of Endocrinology 1998; 139:190-194.

33. Yamada M, Irahara M, Tezuka M, Murakami T, Shima K, Aono T. Serum leptin profiles in the normal menstrual cycles and gonadotrophin treatment cycles. Gynecologic and Obstetrical Investigation 2000; 49:119-223.

34. Lin KC. Changes of circulating leptin levels during normalmenstrual cycle: relationship to estradiol and progesterone. Kaohsiung Journal of Medical Science 1999; 15:597-602.

35. Di Carlo C, Tommaselli GA, Pisano G, Nasti A, Rossi V, Palomba $\mathrm{S}$ et al. Serum leptin levels in postmenopausal women: effect of transdermal hormone replacement therapy. Menopause 2000; 7:3641.

36. Elbers JM, de Roo GW, Popp-Snijders C, Nicolaas-Merkus A, Westerveen E, Joenje BW et al. Effects of administration of 17beta-oestradiol on serum leptin levels in healthy postmenopausal women. Clin Endocrinol (Oxf). 1999; 51:449-54.

37. Cagnacci A, Malmusi S, Arangino S, Zanni A, Rovati L, Cagnacci $P$, et al.

Influence of transdermal estradiol in the regulation of leptin levels of postmenopausal women: double-blind, placebo-controlled study. Menopause 2002; 9:65-71.

38. Lin KC. Increase of leptin levels following administration of estrogen in women with normal menstruation. Kaohsiung J Med Sci 2000; 16:13-19.

39. Castelo-Branco C, Palacios S, Vázquez F, Villero J, Ferrer J, Ascaso $\mathrm{C}$ et al.. Effects on serum lipid and leptin levels of three different doses of norethisterone continuously combined with a fixed dose of 17 beta-estradiol for nasal administration in postmenopausal women: a controlled, double-blind study. Fertil Steril 2007; 88:383389.

40. Laivuori H, Koistinen HA, Karonen SL, Cacciatore B, Ylikorkala O. Comparison between 1 year oral and transdermal oestradiol and sequential norethisterone acetate on circulating concentrations of leptin in postmenopausal women. Hum Reprod. 2001; 16:16321635.

42. Tommaselli GA, Di Carlo C, Di Spiezio Sardo A, Bifulco G, Cirillo $\mathrm{D}$ et al. Serum leptin levels and body composition in postmenopausal women treated with tibolone and raloxifene. Menopause 2006; 13:660-668.

43. Lambrinoudaki IV, Christodoulakos GE, Panoulis CP, Rizos DA, Dendrinos SG, Liakakos T, Augoulea AD, Creatsas GC. Effect of hormone replacement therapy and tibolone on serum leptin levels in postmenopausal women. Maturitas. 2004; 48:107-113.

44. Odabasi AR, Yuksel H, Kafkas S, Demircan S, Karul A, Kozaci $\mathrm{D}$ et al.Effects of tibolone on abdominal subcutaneous fat, serum leptin levels, and anthropometric indices: a 6-month, prospective, randomized, placebo-controlled, double-blind study. Adv Ther. 2006; 23:926-937.

44. Deogou et al. Erenus M, Yörük P. Effects of hormone therapy and tibolone on body composition and serum leptin levels in postmenopausal women. Fertil Steril. Epub ahead of print. 2008 Feb 2. 